\title{
Revealing offering culture suguh sesajen
}

\author{
Anxy Yudhatama Ghozuan \\ Department of Anthropology \\ Faculty of Social and Political Sciences, Universitas Airlangga, Surabaya \\ Address: Jalan Dharmawangsa Dalam, Surabaya 60286 \\ E-mail: anxyyudhatamaghozuan@gmail.com
}

\begin{abstract}
In this modern era, we can get everything we want easily. Human most likely to use technology and think rationally. However, the people in Semen, Tanggalrejo Village, Mojoagung District, Jombang Regency is different because they still believe in the existence of supernatural things and routinely perform offerings activity called "suguh sesajen" to the Tomb of Bariden great grandfather and Mah great grandfather which are believed to be able to obtain good fortune and perform several rituals. This research uses qualitative methods by conducting in-depth interviews and observations. The results of this study indicate that the community still adheres to the tradition "suguh sesajen" offerings and believes in the myth of the occult power of the tomb.
\end{abstract}

Keywords: suguh sesajen, culture, Semen Village

\section{Introduction}

A culture is a way to adapt to the environment continuously that is consider mandatory without any further research whether those things are truly necessary. That kind of perspective emerged so that it is necessary to conduct a comprehensive research to be able to understand a certain behaviour or society. Human is a creature who has an adaptation ability with the surrounding so that they can survive and continue their lives. To be able to survive, human need to understand the characteristic of their surrounding, then they tried to adapt and face the challenges there. Human adaptation is increasingly developing through the learning process in the course of his life, so that humans can use symbols that are meaningful and develop them. Through the symbol of human being able to gather knowledge by choosing attitudes and actions that are considered to provide benefits in adapting to the environment (Masturina 2016).

The diversity of the culture in the society and every culture have their own way to adapt and to encounter as well as to deal with the environment that is why this is the best topic especially anthropology. Various cultures make our country a rich country and have a lot of local wisdom, but this is also able to become one of the breaking factors because of the many differences, therefore we as citizens of Indonesia are obliged to maintain culture and appreciate a difference. The tradition in the society oftenly manifested in a cultural ritual depend on their belief in their society themselves (Sulistiyono 2015).

Beliefs in sacred powers, Islam, and local customs are equilibrium packaged in rituals (Ika et al. 1989). Many people still believe that occult can make themselves better and get good luck, there are a lot of tradition in the society to ask for protection, wealth, luck to the ancestor's spirit especially in Semen, Tanggalrejo Village, Mojoagung District, Jombang Regency.

As javanese, the people in Semen Village has a strong belief to the relation between human and supernatural sacred ritual to fulfil their need towards the society belief of the Bariden great grandfather's cemetery (Masturina 2016). The community carries out rituals to obtain profits, wealth, a mate, by suguh sesajen offering. 


\section{Method}

This study used descriptive qualitative method. The location of the research is in Semen, Tanggalrejo Village, Mojoagung District, Jombang Regency using the people in the area as the main research subject of all the thing regarding suguh sesajen.

The technique of collecting data uses interviews with the people of Semen Village. Observations were also made to see how the process was carried out by the community. After the data is collected, it will then be carried out. The next step is analyzing the data by cross checking every information obtained then selecting and taking important parts to be analyzed (Masturina 2016).

\section{The Research Result and Discussion}

The result from the conducted interview to the Semen Village Society, the researcher got a lot of perspectives regarding this research. The researcher has figures as informant who are lived near to the cemetery site in three Neighborhood Associations (NA) in Semen Village .

Kusnari The Head of NA 001

“...saya berfikir semua orang harus percaya akan adanya hal yang berbau gaib sehingga kita perlu untuk melakukan sugh sesajen kepada Mbah Buyut Bariden dari pengalaman saya setelah melakukan suguh sesajen penghasilan saya lancar dan jauh dari bahaya..."

(...I think everyone has to belief in a magical and supernatural thing so that we always conduct "suguh sesajen" offering to the Bariden great grandfather because from my experience myself, after I did that I get a better income and safer...).

Suntoro The Head of NA 002

“...kalau berbicara masalah Mbah Buyut Bariden saya tidak berani untuk memastikanya kerana hal semacam itu sudah tidak bisa dipikir menggunakan pikiran normal, dan hal semacam itu susah untuk dibicarakan."

(... Speaking of Bariden great grandfather I can not guarantee because this kind of thing is rather illogical and it is hard to talk about).

Sukarlan The Head of NA 003

“...aku tidak terlalu memahami masalah suguh sajen dibuyut bariden karena saya tidak pernah melakukan itu tetapi kalau nyekar setiap tahun saya lakukan karena dari sejarah yang saya peroleh smasih ada hubungan kekeluargaan terhadap Mbah Buyut Bariden..."

(...I don't really understand about Bariden great grandfather "suguh sesajen" offering activity because I never do that, however I do "nyekar" (come to the cemetery) every year because from the history that I got, my family still have relation with Bariden great grandfather...).

Sukiyat Figure in Semen Village

“...lewat sejarah tadi sudah saya jelaskan bahwa suguh sajen itu tidak wajib untuk dilakukan tetapi tetap boleh untuk dilakukan,saya tidak berani melarang orang-orang karena setiap orang memiliki kepercayaan masing-masing..."

(...From the history that I explained before "suguh sesajen" is not a mandatory but everyone still can do it anyway, I can not forbid them to do that because everyone has their own beliefs..).

For instance I still have belief to the mystical things in Javanese culture, we belief in occults and supernatural things (Mulia 2016). Everyone has their own belief to the mystical and supernatural things so as some of the Semen's society who has belief in Bariden great grandfather cemetery and "suguh sesajen" Offering activity even though it is already clear in the history.

\section{The history of Bariden Great Grandfather Cemetery}


Once upon a time, Semen Village was a dense forest, every single tree was so strong and it was really hard to pull out and there were only two people who could did that, they were a husband and wife from Madura called Bariden great grandfather and Man great grandmother and since the trees was so hard to pull out they called this village "Semen" or Cement. They have done that for two years until they both have eight generations in the area but it is not yet certain by the people because both of them suddenly died together in the same day and time. Because of their great contribution they both have special place in this village to spend their forever. They both buried near the field where both of them love to rest while cutting the trees. Once their cemetery was built, there were a lot of bizarre things happened.Every Thursday night there is a tiger, snake, lion, monkey which is believed by the society as manifestation of both Bariden and Nah the great, however it was not as the people belief, according to the story there, both of the ancestors were Muslim and in Islam this kind of belief is not allowed. Religion is a phenomenon in human life, even a necessity that is always needed (Cahyono 2011), because of his holiness they are both blessed with a guard in the form of guardian sacred animals to guard his tomb. The guardian animals are often misinterpreted by the community and are considered as a manifestation of him to be able to be asked for protection and blessings of wealth.

\section{Suguh Sesajen Culture to the Cemetery of Bariden Great Grandfather}

Every sweet Thursday and Friday night (Kamis jump legi) or when they have special occasion some of the people will give offering to the Baiden great grandfather cemetery as well as Mas great grandmother to ask for the good luck and blessed event. The content of the offering is quite the same with what the ancestor did such as yellow janur (young coconut leaves) which means "sing kukuh sing ngening" in Javanese, special cup "kencenge piker", banana king which mean a hope to be able to live like a king. Burning incense is a sign of supernatural foods availability. Kinang and cigarettes which mean giving the things which used to be loved by the spirit, Kinang for the women and cigarette for the men. Long beams means "sing kanggo pinuntun kuwe kaya lanjaran" or to be the guide of life like lanjaran, what it meant by lanjaran is parents who always give guidance to their kids to the right way (Haniyaturroufah 2013). The people believe that offering activity can heal all of the diseases and send the diseases away by doing a ritual called nginep makam (stay the night in the cemetery). The village community considers two sciences, namely the science of healing and the science of harming people. The science of healing is the knowledge possessed by a healer for healing diseases. The science of harming people is the knowledge possessed by sorcerers (magic) and lintrik shaman (witchcraft) to do bad luck to people who are hated or despised by their patients.

People try to fulfil their need by working, the job the people do is not only influenced by the individual choice but also there is also social environment factors (Roikan 2013). Not only social factors but also magical factors in the society especially in Semen Village, the people there usually asked for blessing to the Bariden great grandfather and Man great grandmother by asking for help to the animals that usually show in that area which are believed to be the manifestation of the great grandfather, as for the trader, they usually come so that they can sell well.

Not only men who come but also women also come to ask for the soulmate and in order to be able to have a better image and aura so that they can attract the opposite sex. Imaging is the collection of images which is needed to portray an object in an art. Imaging is closely related to an image due to imaging of a collection of these images (Rini et al. 2014).

Indonesia consists of various islands and each island has its own differences which are become their characteristic. Indonesia is one of the unique countries in the world. Given that Indonesia has a large number of islands, and has high biodiversity and cultural diversity (Iskandar 2016). Suguh sesajen activity in Semen Village should be one of the local wisdom that has to be preserved because this culture becomes a cultural diversity that can become a characteristic of each region. his local wisdom is also important in its meaning as the disclosure of the identity of the Indonesian nation while at the same time uniting the diversity of the nation's culture that is beginning to globalize (Rodiyah et al. 2017). The culture of suguh sesajen should still be done but with the aim of gratitude for all of us towards God 
because of the blessing of this fertile village and always holding "Haul" for Bariden great grandfather and Mah great grandfather.

\section{Conclusion}

The community of Semen and surrounding hamlets, including visitors who came to Bariden great grandfather's tomb and Mah great grandfather, believed the existence of magical powers was used to request protection, luck, wealth and others. This is inseparable from the culture of the Javanese people who are still affected by "dynamism" and "animism" namely the belief in spirits and objects that are believed to be able to influence the success and failure of humans in carrying out life. The Culture of suguh sesajen offerings should still be carried out but with the aim of our gratitude towards God given the village with a fertile, safe and peaceful condition and always holding "Haul" and reciting the verses of the Qur'an for Bariden great grandfather and Mah great grandfather as a gratitude for the role of Semen Village.

\section{References}

Cahyono R (2011) Dinamika Emosi dan Pengalaman Spiritual Beragama: Studi Kualitatif Pengalaman Perubahan Keyakinan Beragama. INSAN 13 (1): 32-40.

Haniyaturroufah (2013) Ritual Sesaji sebagai Bentuk Persembahan untuk Kanjeng. Jurnal Pendidikan, Bahasa, Sastra, dan Budaya Jawa 3 (5): 20-23.

Ika N, Anisa U, \& Zurinani S (1989) Pewarisan Ilmu Dukun dalam Sistem Penyembuhan Tradisional. Masyarakat, Kebudayaan dan Politik 30: 48-58.

Iskandar J (2016) Etnobiologi dan Keragaman Budaya di Indonesia. UMBARA: Indonesian Journal of Anthropology 1 (1): 27-42.

Kusnari (2017) [Personal communication].

Masturina A (2016) Makna Sendang Made bagi Masyarakat Desa Made Kecamatan Kudu Kabupaten Jombang. AntroUnairdotNet 5 (3):437-449.

Mulia SW (2016) Realisme Magis dalam Novel Simple Miracles Doa dan Arwah Karya Ayu Utami. Tesis, Universitas Airlangga, Surabaya.

Rini AML, Martono, \& Seli S (2014) Citra Perempuan pada Novel Hati Sinden Karya Dwi Rahyuningsih (Kajian Feminisme Marxis). Jurnal Pendidikan dan Pembelajaran 3 (4): 1-17.

Rodiyah S, Khadijah ULS, \& Kurniasih N (2017) Naskah Kuno sebagai Identitas Budaya di Masyarakat Kabuyutan Ciburuy Bayongbong Kabupaten Garut. Record and Library Journal 3 (1): 97-107.

Roikan (2013) Mitos Dan Etos: Budaya Kerja Merantau Masyarakat Kampung Soto Ayam Lamongan. BioKultur 2 (2): 113.

Sukarlan (2017) [Personal communication].

Sukiyat (2017) [Personal communication].

Sulistiyono I (2015) Ken-Duren Wonosalam (Studi Deskriptif: Makna Ken-Duren Wonosalam pada Masyarakat. AntroUnairdotNet 4 (1): 77-85.

Suntoro (2017) [Personal communication]. 